\title{
A low-cost method for monitoring snow characteristics at remote field sites
}

\author{
Rosamond J. Tutton and Robert G. Way \\ Department of Geography and Planning, Queen's University, Kingston, ON K7L 3N9, Canada \\ Correspondence: Robert G. Way (robert.way@queensu.ca)
}

Received: 21 July 2020 - Discussion started: 29 July 2020

Revised: 24 October 2020 - Accepted: 2 November 2020 - Published: 4 January 2021

\begin{abstract}
The lack of spatially distributed snow depth measurements in natural environments is a challenge worldwide. These data gaps are of particular relevance in northern regions such as coastal Labrador where changes to snow conditions directly impact Indigenous livelihoods, local vegetation, permafrost distribution and wildlife habitat. This problem is exacerbated by the lack of cost-efficient and reliable snow observation methods available to researchers studying cryosphere-vegetation interactions in remote regions. We propose a new method termed snow characterization with light and temperature (SCLT) for estimating snow depth using vertically arranged multivariate (light and temperature) data loggers. To test this new approach, six snow stakes outfitted with SCLT loggers were installed in forested and tundra ecotypes in Arctic and subarctic Labrador. The results from 1 year of field measurement indicate that daily maximum light intensity (lux) at snow-covered sensors is diminished by more than an order of magnitude compared to uncovered sensors. This contrast enables differentiation between snow coverage at different sensor heights and allows for robust determination of daily snow heights throughout the year. Further validation of SCLT and the inclusion of temperature determinants is needed to resolve ambiguities with thresholds for snow detection and to elucidate the impacts of snow density on retrieved light and temperature profiles. However, the results presented in this study suggest that the proposed technique represents a significant improvement over prior methods for snow depth characterization at remote field sites in terms of practicality, simplicity and versatility.
\end{abstract}

\section{Introduction}

Snow cover and snow depth are among the Global Climate Observing System's (GCOS) essential climate variables (Bojinski et al., 2014) and are critical components of global and regional energy balances (Olsen et al., 2011; Pulliainen et al., 2020). The global snow albedo effect influences all humans, but consequences of changing snow conditions for those living in cold climate and alpine regions are especially pronounced (Ford et al., 2019; Lemke et al., 2007). Accurate characterization of snow depth is important for hydroelectric operations, freshwater and land resource availability to communities, and prediction of climate change impacts (Hovelsrud et al., 2011; Mortimer et al., 2020; Sturm et al., 2005; Thackeray et al., 2019; Wolf et al., 2013). Changes to snow depth and snow cover duration in Arctic and alpine tundra caused by enhanced shrub and tree growth can result in warmer ground temperatures, permafrost thaw and further vegetation expansion (Callaghan et al., 2011; Wilcox et al., 2019). Unlike rainfall, snowfall is hard to catch, melts differentially (Archer, 1998) and is structurally, mechanically and thermally anisotropic (Leinss et al., 2016). Our ability to monitor in situ snow conditions has historically been limited to open areas near larger communities and airfields where large meteorological apparatus are established (Goodison, 2006). As such, standardized measurement of snow remains a challenge in remote regions where existing stations cannot represent the diversity of snow conditions across topography, vegetation and snow wind scouring (Brown et al., 2012, 2003; Derksen et al., 2014).

Satellite remote sensing platforms are unable to directly measure snow depth and thermal properties in most environments (Boelman et al., 2019; Kinar and Pomeroy, 2015; Sturm, 2015) and depend on a very limited network of sur- 
face validation sites located in open areas (Trujillo and Lehning, 2015). Further, acquisition, establishment and maintenance of stationary weather instrumentation used by government and industry services is costly outside of regional centres, and this infrastructure is not designed to represent forest conditions (Goodison, 2006). This leads to data-sparse areas at high latitudes and in mountainous regions, as well as spatially biased representation of snow characteristics in research and modelling which reduce our ability to predict impacts of climate change on snow and ground conditions (Domine et al., 2019; Pulliainen et al., 2020). Cost-efficient snow measurement also facilitates better representation of spatial variability of key snow characteristics such as snow water equivalent across a basin or region of interest.

To compensate for the lack of automated, spatio-temporal measurements, field researchers in ecological, hydrological and cryospheric domains have made use of low-cost methods such as vertically arranged temperature loggers (de Pablo et al., 2017; Gilbert et al., 2017; Reusser and Zehe, 2011; Throop et al., 2012) and trail cameras with marked stakes (Bongio et al., 2019; Dickerson-Lange et al., 2017; Farinotti et al., 2010; Fortin et al., 2015). These options are relatively low cost (CAD 250 (trail camera) to CAD 700 (10 iButtons) per stake) (Table S1 in the Supplement) but have clear disadvantages. For example, iButton temperature loggers can have a low precision $\left( \pm 0.5^{\circ} \mathrm{C}\right)$ and sampling frequency ( $4 \mathrm{~h}$ sampling rate for less than a year of data) (Lewkowicz, 2008), experience frequent clock slippage, and require specific modifications due to imperfect waterproofing. Trail camera setups often require extensive manual processing, depend on weather conditions (interpretable images, camera battery life) and do not allow determination of other snow characteristics beyond snow heights (Farinotti et al., 2010; Garvelmann et al., 2013).

In this study, we present results from a novel low-cost technique for snow depth estimation that can be efficiently applied at remote field sites. With a similar per-site cost (Table S1), the method alleviates some of the challenges associated with other low-cost methods while offering a direct method of estimating snow characteristics in natural conditions. Building on the practice of using temperature loggers (Danby and Hik, 2007; Lewkowicz, 2008), we propose the snow characterization with light and temperature (SCLT) technique, which uses vertically arranged dual light and temperature data loggers together to produce reliable estimates of snow characteristics with minimal analysis across ecotones. The current generation of SCLT-based snow thickness estimation relies most on light measurements, but SCLT's dual sensor configuration will enable future use of multivariate statistical techniques to improve snow depth estimation. We tested the SCLT method for 1 year at six field sites located in forested and shrub-tundra locations in subarctic and Arctic Labrador, north-eastern Canada. Our results show sufficient promise that we believe there is significant benefit to sharing first results with the broader snow science com- munity. Adoption of this method will facilitate a more prolific network of snow measurements in real-world conditions and will inform modelling and climate change adaptation measures while enhancing core understanding of cryospheric processes.

\section{Study area}

The snow characterization with light and temperature (SCLT) method was tested at six field sites located in subarctic and Arctic Labrador (north-east Canada). Field sites were within regions governed or managed by the Nunatsiavut Government, NunatuKavut Community Council and/or Innu Nation. The overall region has a strong coastal-continental gradient in air temperature, with higher snowfall amounts and colder temperatures than similar western Canadian latitudes due to the Labrador Current (Banfield and Jacobs, 1998; Brown et al., 2012; Maxwell, 1981; Way et al., 2017). Mean annual air temperature ranges from around $-8^{\circ} \mathrm{C}$ (Torngat Mountains Ecodistrict) to $2^{\circ} \mathrm{C}$ (L'Anse Amour Ecodistrict), and regional total precipitation ranges from $546 \mathrm{~mm}$ (Cape Chidley Ecodistrict) to $1248 \mathrm{~mm}$ (Mealy Mountain Ecodistrict) (Riley et al., 2013). On average, regional snow and ice cover is present from November to May (Brown et al., 2012); however, snow cover duration has rapidly declined in northern Labrador and climate models predict further reductions in snow cover duration in the future (Barrette et al., 2020; Brown et al., 2012). The six SCLT field testing sites (Table 1) cover a latitudinal range of 52.7 to $58.5^{\circ} \mathrm{N}$ and are mostly located in forested ecodistricts (high boreal forest, low subarctic forest and mid-subarctic forest) where the dominant vegetation types are black spruce, white spruce, balsam fir and eastern larch (Roberts et al., 2006; Riley et al., 2013) (Fig. 1; Table 1). One site (BaseSnow) is located in low-Arctic shrub tundra (Torngat Mountains Ecodistrict) where dominant upright shrub species are alder and dwarf birch (Riley et al., 2013). The forested sites (Amet11, Amet12, Amet17, Amet28 and Amet19) are at a lower latitude and receive at minimum $7.6 \mathrm{~h}$ of daylight while the higher-latitude shrub-tundra site (BaseSnow) receives at minimum $6.3 \mathrm{~h}$ of daylight (Bird and Hulstrom, 1981).

\section{Methods}

\subsection{Theoretical approach}

The snow characterization with light and temperature (SCLT) method is based on prior research demonstrating that light transmission is inhibited by snow cover and that overlying snow layer characteristics impact the magnitude and rate of light transmission through the snowpack (Fig. 2) (Libois et al., 2013; Perovich, 2007). The SCLT method is an evolution of a low-cost method, first described by Danby and Hik (2007) and Lewkowicz (2008), that uses vertically arranged 
Table 1. Site specifications for the six SCLT sites including site name, latitude, longitude, elevation, ecotype and SCLT data collection period.

\begin{tabular}{llrrrll}
\hline Site ID & Full site name & $\begin{array}{r}\text { Latitude } \\
\left({ }^{\circ} \mathrm{N}\right)\end{array}$ & $\begin{array}{r}\text { Longitude } \\
\left({ }^{\circ} \mathrm{E}\right)\end{array}$ & $\begin{array}{r}\text { Elevation } \\
(\mathrm{m})\end{array}$ & $\begin{array}{l}\text { Vegetation } \\
\text { ecotype }\end{array}$ & SCLT data collection period \\
\hline Amet11 & Mealy South Lower & 52.83 & -60.10 & 265 & Taiga forest & 13 Sep 2018 to 24 Jul 2019 \\
Amet12 & Mealy South Upper & 52.79 & -60.03 & 467 & Taiga forest & 13 Sep 2018 to 24 Jul 2019 \\
Amet17 & Goose Bay Upper & 53.30 & -60.54 & 271 & Boreal forest & 14 Oct 2018 to 5 Aug 2019 \\
Amet28 & Aliant Tower Lower & 53.09 & -61.80 & 390 & Taiga forest & 3 Sep 2018 to 12 Aug 2019 \\
Amet29 & Aliant Tower Upper & 53.11 & -61.80 & 526 & Taiga forest & 3 Sep 2018 to 12 Aug 2019 \\
BaseSnow & Torngat Basecamp & 58.45 & -62.80 & 3 & Shrub tundra & 7 Aug 2018 to 19 Aug 2019 \\
\hline
\end{tabular}

temperature measurements and diurnal temperature fluctuations to estimate the date of snow cover at a given height (Lewkowicz, 2008). SCLT uses simultaneous measurements of light intensity and temperature together to characterize snowpack characteristics.

\subsection{Field implementation of the SCLT method}

Wooden stakes $(1.8 \mathrm{~m})$ were outfitted with vertically arranged HOBO MX2202 Pendant wireless temperature/light data loggers (Onset Computer Corporation, 2020) anchored to $1.0 \mathrm{~m}$ metal poles driven into the ground (Table S1). Loggers were positioned at heights of $10,20,30,40,50,60$, $80,100,120$ and $160 \mathrm{~cm}$ above the ground surface and thus characterize near-surface snow layers at a higher resolution than upper layers (Figs. 2, 3). The specific heights used for loggers' positions were set to maintain continuity with prior snow estimates made at these sites with iButton techniques (e.g. Way and Lewkowicz, 2018), but other configurations (e.g. $10 \mathrm{~cm}$ intervals) may be preferred for other non-permafrost applications. Visible light intensity and temperature was recorded at intervals of $2 \mathrm{~h}$ (even intervals), and data were downloaded in the field via the HOBOmobile app (Onset Computer Corporation, 2020). At each site, ground surface temperature, ground temperature (approximately $1 \mathrm{~m}$ depth) and air temperature were also collected following Way and Lewkowicz (2018). Initial testing of the SCLT method covered the period of September 2018 to August 2019.

\subsection{Data processing and analysis}

We calculated SCLT-derived snow surface heights using SCLT with three unique but conceptually similar approaches. All analyses assume that snow cover at a given height occurs when daily maximum light intensity or daily temperature standard deviation drops below an empirical threshold. The first approach applied change-point analysis to raw light intensity measurements with the assumption that sudden changes in light intensity recorded at a logger are indicative of complete or partial snow coverage. The position of change-point segments was determined using the pruned exact linear time (PELT) test method, a cost minimization function as described by Killick et al. (2012), using a asymptotic penalty of 0.1 (resulting in $90 \%$ confidence) (Killick et al., 2012). By removing non-optimal solution paths, this method provides moderate sensitivity (Aminikhanghahi and Cook, 2017) and fast processing time (Beaulieu et al., 2012; Wambui et al., 2015). A logger is deemed snow covered if a drop in light intensity causes change-point segments to fall below a threshold derived empirically.

Snow cover thresholds were defined as the minimum of the daily maximum light intensities during no-snow conditions at a data logger. No-snow conditions were considered days where the daily maximum temperature recorded at a given logger was above $0.5^{\circ} \mathrm{C}$. This approach resulted in thresholds and ranges of daily maximum light intensities that varied from logger to logger (Figs. 4, S1). Application of change-point analysis with the empirical thresholds enabled detection of stepwise increases (or decreases) in snow surface heights relative to a logger's position (Fig. 5). Estimated snow depth was floored to the closest logger height, which, when using raw data, resulted in uncertainties of $\pm 10 \mathrm{~cm}$ at lower positions and up to $\pm 40 \mathrm{~cm}$ for the top position.

The second approach applied to SCLT data uses similar logic as the first method but takes advantage of the high correlation between loggers at different heights through interpolation (Table S2). Daily maximum light intensity data were interpolated through time and vertical height using a modified thin plate spline interpolation designed for spatial processes from the fields R package (Nychka et al., 2017). Mean absolute error (MAE) of daily maximum interpolations ranged from 0.089-0.398 lux (logarithmic) for light and $0.099-2.01^{\circ} \mathrm{C}$ for temperature (Table S2). Snow cover was estimated from interpolated SCLT data with two different techniques: (1) standard change-point analysis (PELT method, asymptotic penalty of $10 \%$ ) using the mean threshold using pooled data for all loggers at a given stake; and (2) using the minimum, mean and maximum of the empirical snow cover thresholds from all loggers across a stake (contour method) (Fig. S1).

A third approach based entirely on temperature (Fig. S2) was used for comparison with the light-intensity-based methods presented above. Estimation of snow depth with only temperature data is widespread in the ecological and per- 


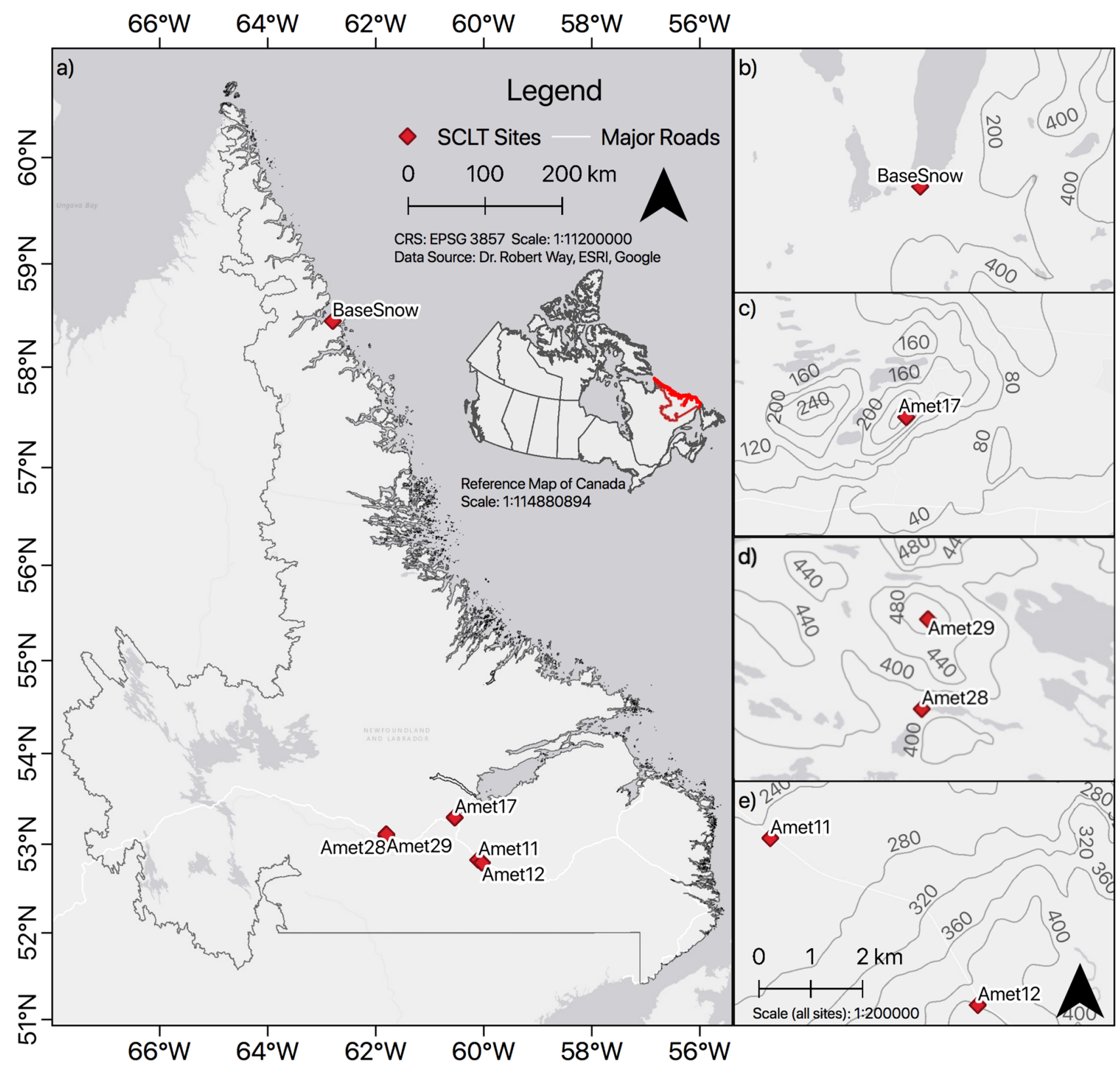

Figure 1. (a) Geographic distribution of light and temperature snow stake sites, with detailed topographic depictions of (b) BaseSnow in Torngat Mountains National Park, (c) Amet17 close to the municipality of Happy Valley-Goose Bay (HVGB), (d) Amet28 and Amet29 along the Trans-Labrador Highway between Churchill Falls and HVGB, and (e) Amet11 and Amet12 along the Trans-Labrador Highway south-east of HVGB.

mafrost literature and relies on measuring attenuation of diurnal variability in the snowpack (Danby and Hik, 2007; Lewkowicz, 2008). We apply change-point analysis (PELT method, asymptotic penalty of $10 \%$ ) to daily temperature standard deviations measured at each logger using the minimum standard deviation measured during no-snow conditions (Tmax $>0.5^{\circ} \mathrm{C}$ ) for each height as an empirical threshold. A second condition was added where minimum temperature on a given day must be less than or equal to $0.5^{\circ} \mathrm{C}$ for snow cover to be present.

\section{Results}

\subsection{Estimating snow depth using lux measurements}

We used the SCLT method to estimate snow depth through the winter for 2018-2019 at six remote sites across Labrador. The first analysis method derives the snow depth using a change-point analysis of the raw daily aggregates and the second uses interpolated light intensity data. A third method 


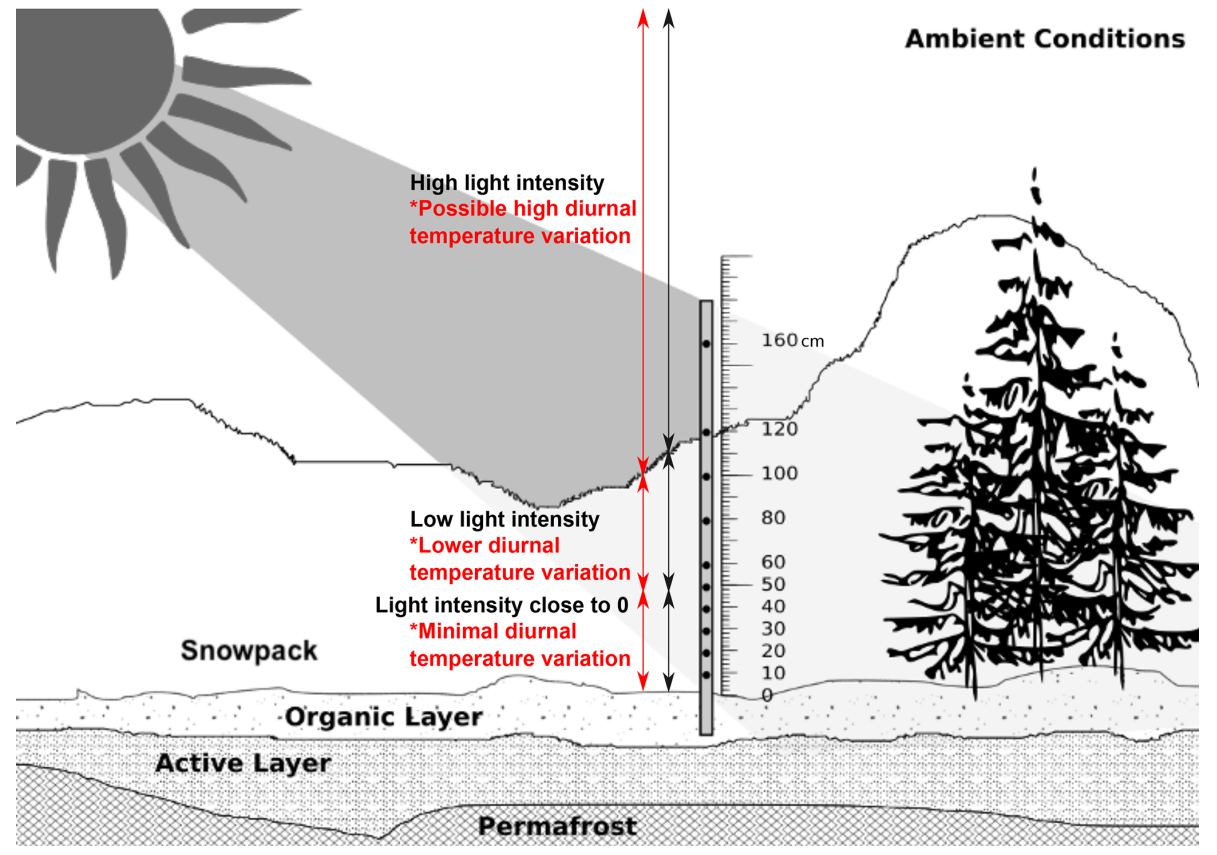

Figure 2. Conceptual diagram of the snow characterization with light and temperature (SCLT) method as implemented in this study. It is hypothesized that increases in snow depth will lead to sudden drops in light intensity measured by data loggers due to scattering and reflection in the snowpack (Perovich, 2007). A snow-covered logger is assumed to have mean values which are lower than ambient light intensity while temperature is assumed to remain at or just below freezing. Increased snow depth is assumed to result in less light penetration and decreasing diurnal temperature variation at lower logger heights. Impacts of snow ageing and density variations are expected to impact these processes but are not explored in the present analysis.

is entirely based on temperature and is presented for a comparison to data analysis methods used in prior studies.

\subsection{Change-point analysis with raw light intensity measurements}

At forested sites (Amet11, Amet12, Amet17, Amet28, Amet29), snow accumulated stepwise beginning in midOctober with a maximum depth reached between March and April followed by rapid snowmelt in early to mid-May (Fig. 6). At the shrub-tundra site (BaseSnow), snow cover was generally thin over much of the winter, with smaller periods of accumulation in the late fall and early winter. At BaseSnow, maximum snow thickness was reached in midMarch to mid-April and a complete melt occurred by early May. Across all sites the snow cover duration ranged from $174 \mathrm{~d}$ (BaseSnow) to $229 \mathrm{~d}$ (Amet12), with an average duration of $215 \mathrm{~d}$ (Table 2). Mean January snow depth was also lowest at BaseSnow $(\sim 11 \mathrm{~cm})$ and highest at Amet12 $(\sim 103 \mathrm{~cm})$. In 2018-2019, all SCLT sites except for BaseSnow had a snowpack taller than the uppermost data logger $(160 \mathrm{~cm} ; 120 \mathrm{~cm}$ at Amet1 1 due to a logger failure) for anywhere between $8 \mathrm{~d}$ (Amet28) and $84 \mathrm{~d}$ (Amet11) (Table 2).
Table 2. Snow cover duration, maximum snow depth, duration at maximum depth and mean January snow depth for each SCLT site for 2018-2019 using the change-point method with raw lux values.

\begin{tabular}{lrrrr}
\hline Site & $\begin{array}{r}\text { Snow cover } \\
\text { duration }\end{array}$ & $\begin{array}{r}\text { Maximum } \\
\text { snow depth }\end{array}$ & $\begin{array}{r}\text { Duration at } \\
\text { max depth }\end{array}$ & $\begin{array}{r}\text { Mean January } \\
\text { snow depth }\end{array}$ \\
\hline Amet11 & $212 \mathrm{~d}$ & $>120 \mathrm{~cm}$ & $84 \mathrm{~d}$ & $87.1 \mathrm{~cm}$ \\
Amet12 & $229 \mathrm{~d}$ & $>160 \mathrm{~cm}$ & $80 \mathrm{~d}$ & $103.2 \mathrm{~cm}$ \\
Amet17 & $228 \mathrm{~d}$ & $>160 \mathrm{~cm}$ & $81 \mathrm{~d}$ & $100.6 \mathrm{~cm}$ \\
Amet28 & $220 \mathrm{~d}$ & $>160 \mathrm{~cm}$ & $8 \mathrm{~d}$ & $101.3 \mathrm{~cm}$ \\
Amet29 & $226 \mathrm{~d}$ & $>160 \mathrm{~cm}$ & $27 \mathrm{~d}$ & $98.7 \mathrm{~cm}$ \\
BaseSnow & $174 \mathrm{~d}$ & $40 \mathrm{~cm}$ & $9 \mathrm{~d}$ & $10.6 \mathrm{~cm}$ \\
\hline
\end{tabular}

\subsection{Snow depth estimation with interpolated light intensity measurements}

Light intensity was interpolated through time and height, and two analysis techniques were applied to the interpolated data (Fig. 7). The first, which used change-point analysis, accumulated snow from late October to late January for Amet11, Amet12 and Amet17 with snow cover above the top logger (greater than $120 \mathrm{~cm}$ for Amet11 and $160 \mathrm{~cm}$ for Amet12 and Amet17) until spring snowmelt in late April to early May. With the interpolated change-point method, Amet28 accumulated snow until April when it reached a maximum snow depth of $133 \mathrm{~cm}$ on 21 March 2019 and melted 

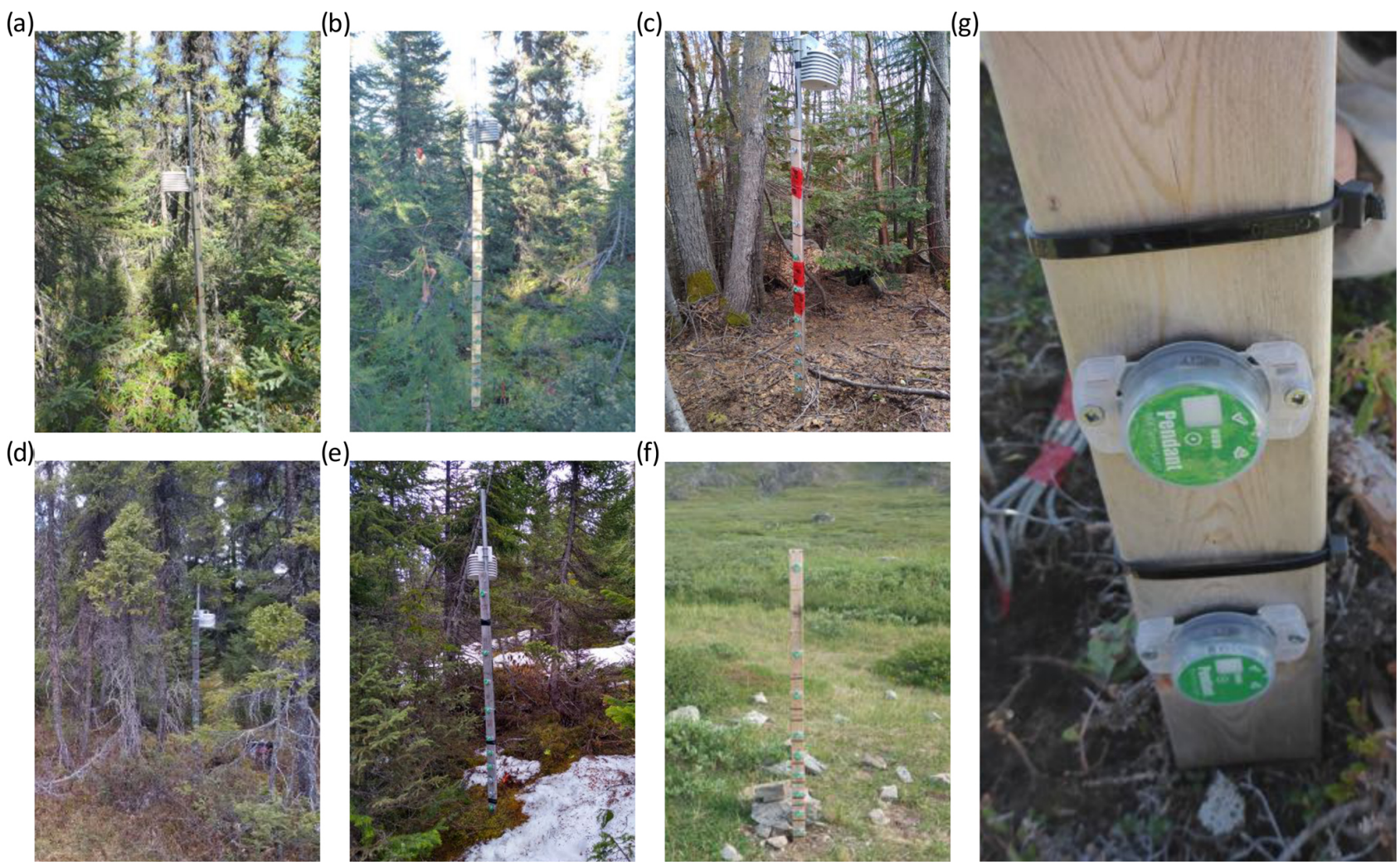

Figure 3. Field photos of all SCLT measurement sites for 2018-2019 and (g) a close-up of logger installation onto stake. These include (a) Amet11, (b) Amet12, (c) Amet17, (d) Amet28, (e) Amet29 and (f) BaseSnow.

(a) Amet11

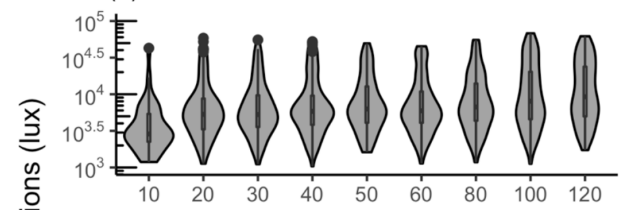

(c) Amet17

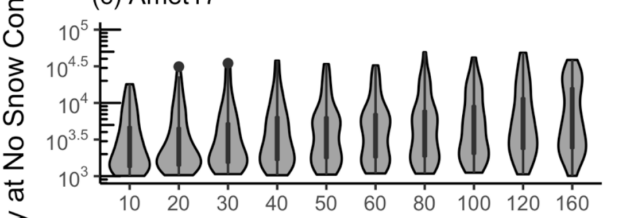

(e) Amet29

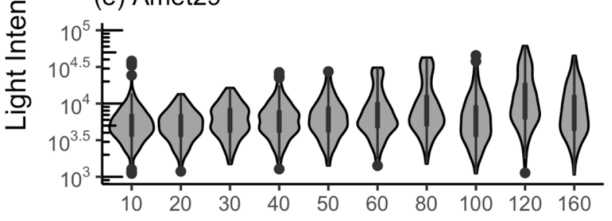

(b) Amet12

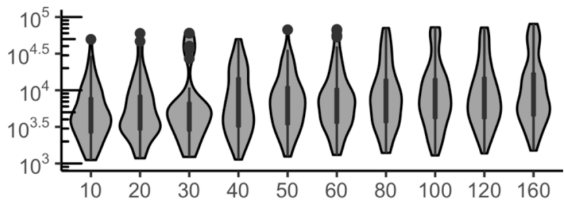

(d) Amet28

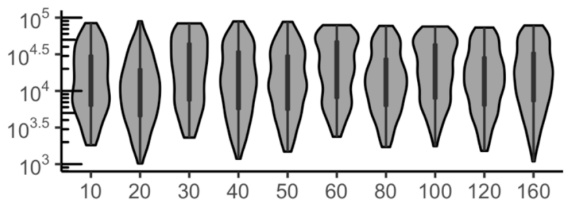

(f) BaseSnow

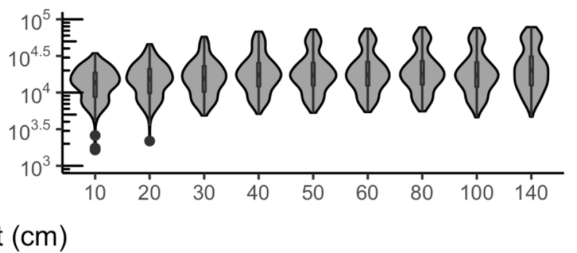

Figure 4. Violin plot (rotated kernel density) showing the probability density and distribution of daily maximum light intensities (logarithmic scale) when the daily maximum temperature is above $0.5^{\circ} \mathrm{C}$ at (a) Amet11, (b) Amet12, (c) Amet17, (d) Amet28, (e) Amet29 and (f) BaseSnow. Minimum values were used as the individual logger thresholds for the change-point analysis and pooled thresholds were used for the range of thresholds used in the interpolated analysis. 
(a)

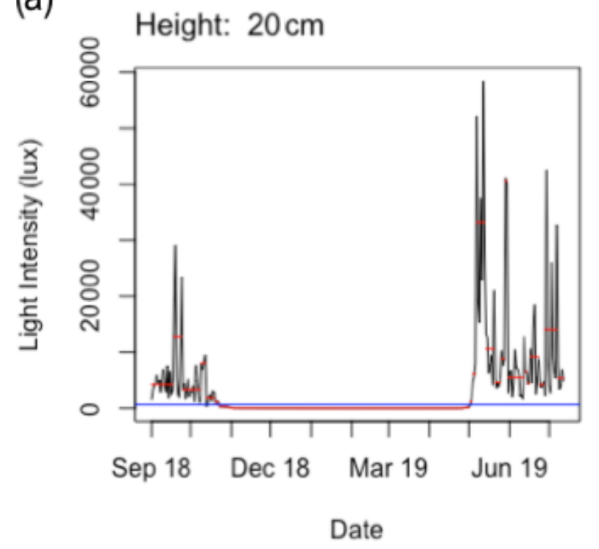

(c)

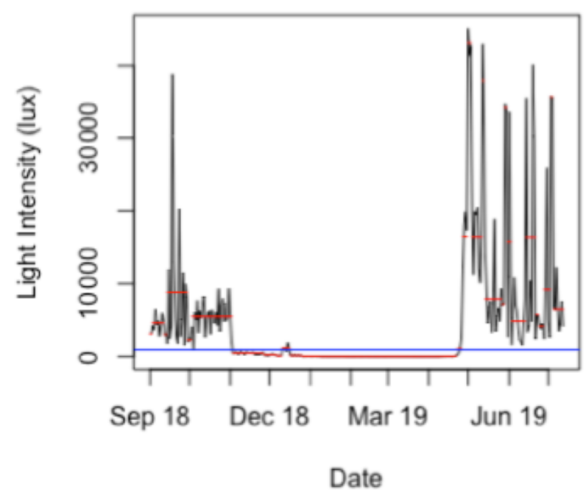

(b)

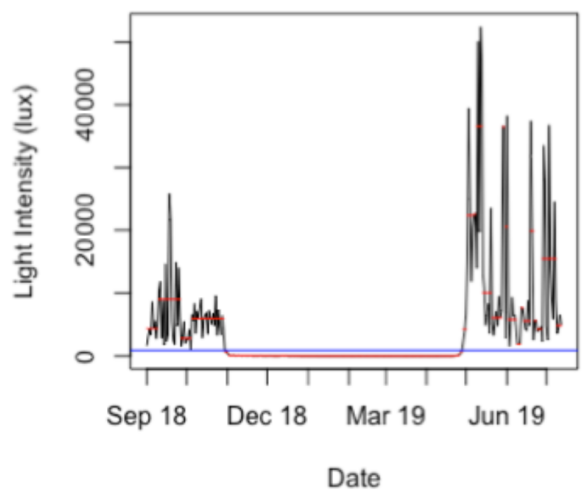

(d)

Height: $100 \mathrm{~cm}$

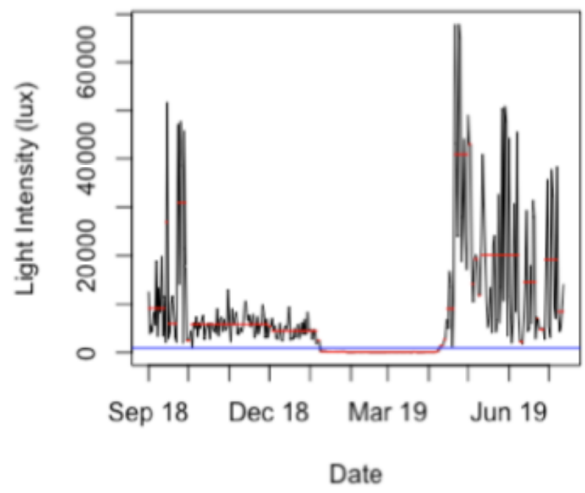

Figure 5. Change-point analysis applied to (a) 20, (b) 40, (c) 60 and (d) $100 \mathrm{~cm}$ height loggers along Amet11. The red line shows changepoint segment means, and the blue line shows the no-snow light intensity threshold for each logger. Snow cover occurs at a given logger when the change-point segment drops below the no-snow threshold.

from late April until mid-May. At Amet29 snow depth exceeded the top logger $(160 \mathrm{~cm})$ from mid- to late April and melted throughout May (Fig. 7). BaseSnow showed a thinner snow cover with short periods of accumulation in the late fall (November), late December and February with a maximum snow depth of $31 \mathrm{~cm}$ in late January. The interpolated change-point analysis resulted in snow cover durations ranging from $177 \mathrm{~d}$ (BaseSnow) to $234 \mathrm{~d}$ (Amet12) and mean January snow depth ranging from $17 \mathrm{~cm}$ (BaseSnow) to $120 \mathrm{~cm}$ (Amet17).

The second approach applied to interpolated data used the minimum, mean and maximum stake-wide pooled thresholds to produce a range of contours showing potential snow depths for each day. The SCLT snow depth using mean thresholds showed a similar pattern to the change-point analysis described above with accumulation from late October to late January, with the notable exception that snow cover at Amet28 exceeded the top logger with this method (Fig. 7). BaseSnow showed dispersed accumulations between the late fall and early spring with rapid melt occurring in mid-April and a maximum snow depth of $43 \mathrm{~cm}$ on 23 December 2018 .
Snow cover duration ranged from $178 \mathrm{~d}$ (BaseSnow) to $200 \mathrm{~d}$ (Amet17) and mean January snow depth ranged from $23.0 \mathrm{~cm}$ (BaseSnow) to $120 \mathrm{~cm}$ (Amet17) (Fig. 7). Applying the contour approach to 2018-2019 winter SCLT data leads to mean time-varying snow depth uncertainty ranges from $3 \pm 3 \mathrm{~cm}$ (Amet17) to $15 \pm 6 \mathrm{~cm}$ (Amet28).

\subsection{Comparison of SCLT lux methods}

Raw and interpolated light-intensity-based methods showed similar periods of snow onset with gradual snow accumulation from October to May for the Amet sites, but the raw change-point analysis resulted in a shorter duration of snow cover compared to the interpolated data at all sites (Fig. 7). Generally, the raw change-point method showed larger single-day increases in estimated snow depth, while the same method applied to interpolated data resulted in smaller, more frequent accumulations. Application of the contour method (using minimum, mean and maximum thresholds) resulted in smooth periods of accumulation and transport or melt, but they were mostly similar to the changepoint-based estimates (Fig. 7). Change-point analysis and 
(a) Amet11

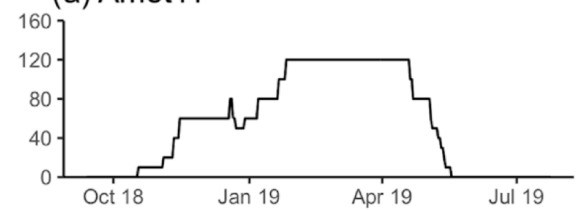

(c) Amet17

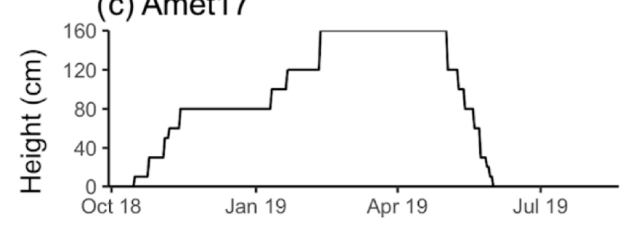

(e) Amet29

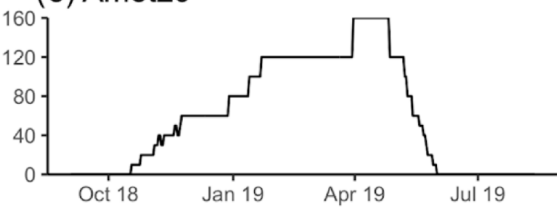

(b) Amet12

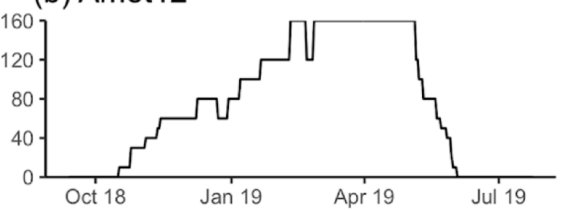

(d) Amet28

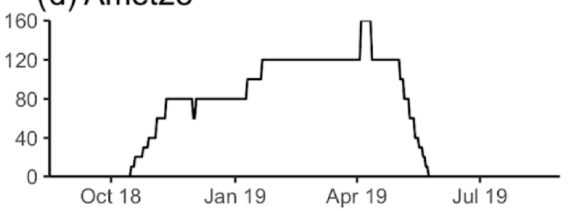

(f) BaseSnow

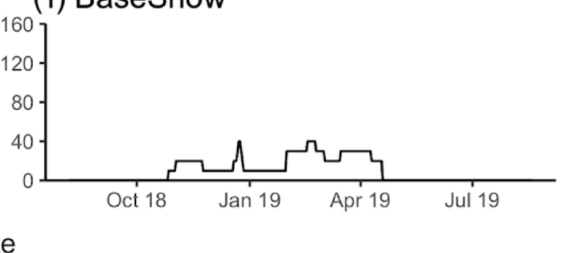

Figure 6. Snow depth over 2018-2019 derived using change-point analysis of raw lux values from loggers at each SCLT measurement site including (a) Amet11, (b) Amet12, (c) Amet17, (d) Amet28, (e) Amet29 and (f) BaseSnow. Top logger positions ranged from $120 \mathrm{~cm}$ (Amet11 and BaseSnow) to $160 \mathrm{~cm}$ (Amet12, Amet17, Amet28, Amet29) and cannot detect snow depths above this height.

(a) Amet11

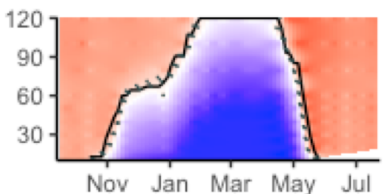

(c) Amet17

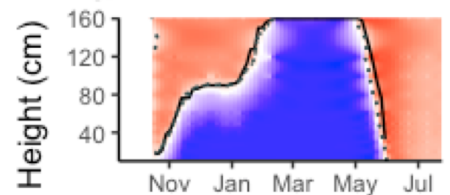

(e) Amet29

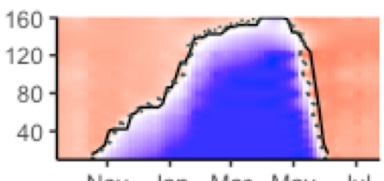

Date (2018-2019) (b) Amet12

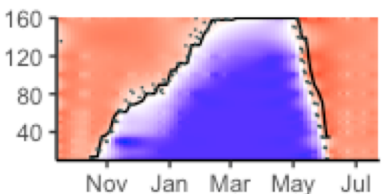

(d) Amet28

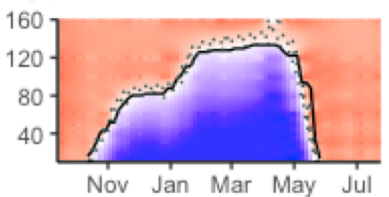

(f) BaseSnow

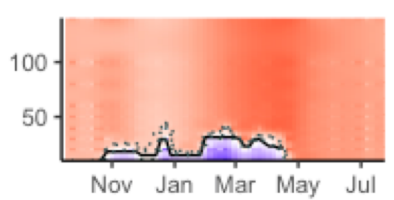

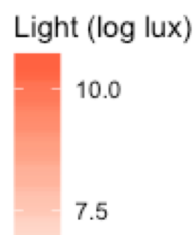

5.0

2.5

0.0

- Change-point Analysis

.... Interpolated Thresholds

Figure 7. Interpolated lux measurements presented as an $X-Y-Z$ plot on a log-scale for each SCLT measurement site including (a) Amet11, (b) Amet12, (c) Amet17, (d) Amet28, (e) Amet29 and (f) BaseSnow. Estimated snow depths are presented for change-point analysis (black) and the mean of the no-snow thresholds (contour method; dotted).

contours using interpolated data resulted in similar mean January snow depths for all stations with a mean difference of $3 \pm 2 \mathrm{~cm}$ (Table 3 ). The mean January snow depth was significantly lower using the change-point method on the raw data at all stations, with differences ranging from $10.2 \mathrm{~cm}$ (Amet28) to $18.4 \mathrm{~cm}$ (Amet17) (Table 3).
Comparison of a forested (Amet12) and shrub-tundra site (BaseSnow) showed earlier snowmelt with the raw changepoint analysis at the former site but no clear differences in melt at the latter site (Fig. 8). The raw change-point method also showed a period of snow removal or melt in the early to mid-winter at the forested site, though this was not evident 
(a) Amet12

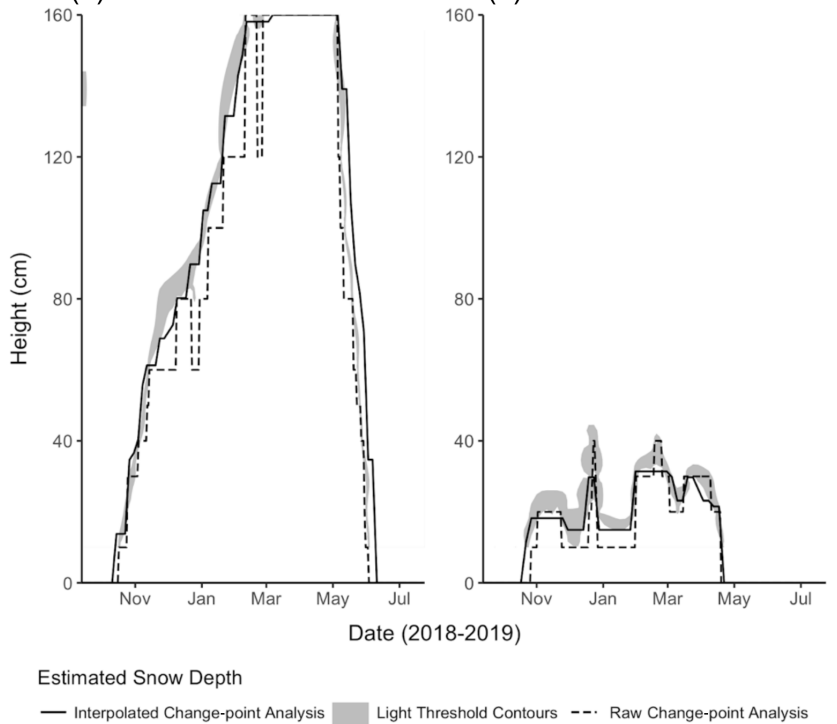

Figure 8. Comparison of snow depths derived with light-based methods for (a) a forested site (Amet12) and (b) a shrub-tundra site (BaseSnow). Snow depth estimates are provided for raw changepoint analysis (dashed lines), interpolated change-point analysis (black line), and interpolated contours using minimum and maximum snow cover thresholds (grey shading).

in the interpolated data (Fig. 8). All three light-based methods showed a consistently low snowpack at the shrub-tundra site (BaseSnow) with greater overall variability in the raw change-point analysis (Fig. 8).

\subsection{Estimating snow depth using temperature measurements}

Application of the temperature-based change-point analysis resulted in forested stations (all Amet sites) showing snow accumulation starting in mid- to late October but not until late December at the shrub-tundra site (BaseSnow). All temperature-based snow depth estimates showed a drop in snow depth in late December (Fig. 9). Amet11 reached a maximum snow depth of $100 \mathrm{~cm}$ in February but periodically dropped to $50 \mathrm{~cm}$ throughout the winter, with a rapid decline in late April to early May (Fig. 9). Amet12 and Amet17 exceeded the top logger in February but had sudden drops in snow depth throughout the winter into early spring. Amet 28 and Amet 29 both accumulated snow gradually until early April with peak snow depths of greater than 120 and $160 \mathrm{~cm}$, respectively. Melt is inferred to have occurred at all SCLT sites excluding BaseSnow between late April and late May. At BaseSnow, spikes in snow cover up to $30 \mathrm{~cm}$ occurred in late December and late March to early April. Excluding these peaks, snow cover at BaseSnow remained at $0 \mathrm{~cm}$ throughout much of the snow season (Fig. 9). With the univariate temperature analysis, snow cover duration ranged from $104 \mathrm{~d}$
(BaseSnow) to $227 \mathrm{~d}$ (Amet12 and Amet17), and mean January snow depth ranged from $0 \mathrm{~cm}$ (BaseSnow) to $101 \mathrm{~cm}$ (Amet12).

\subsection{Comparison of light and univariate temperature methods}

Estimated snow depth using temperature showed large drops in the late fall and mid-winter at most sites that were not evident in the light-intensity-based methods. Temperature-based snow depths consistently produced shorter snow durations and less snow accumulation at all sites (Fig. 9; Table 3). For the forested sites (Amet sites), the differences in mean January snow depth between the temperature change point and the raw SCLT change point ranged from $2 \mathrm{~cm}$ (Amet12) to $22 \mathrm{~cm}$ (Amet17) (Table 3), though an even greater difference was found when comparing interpolated data (mean difference of $27 \pm 11 \mathrm{~cm}$ ). At BaseSnow (shrub tundra), the temperature method estimated a snow depth of $0 \mathrm{~cm}$ in January while the light-based methods estimated mean snow depths between 10 and $23 \mathrm{~cm}$ (Table 3 ).

Temporal variability in snow depths was examined using Pearson correlation coefficients calculated across sites and methods between December and January (avoiding snow depths exceeding maximum logger heights). Amongst the four methods examined, snow depths derived using lightbased methods were highly correlated with one another ( $r=0.7$ to $r=0.98$ ) but were much less correlated with the temperature-based snow depths (Fig. 10). Raw changepoint analysis using light provided the highest mean correlation with the temperature-based snow depths across sites $(r=0.85)$. Overall, cross-method correlations were highest for Amet29 and lowest for BaseSnow, reflecting the highly variable snow conditions at the latter site (Fig. S3).

\section{Discussion}

\subsection{Evaluation of SCLT performance}

Evaluation of the snow characterization with light and temperature (SCLT) method in subarctic and Arctic Labrador over winter 2018-2019 showed that the technique can reliably and consistently determine snow depth in both forested and shrub-tundra environments. The raw change point requires minimal processing time and is easiest to implement, but by ignoring the inter-associations between measurements at different heights it will inherently floor snow depth to the closest logger, leading to larger errors than with interpolated data. Interpolation of SCLT data were also able to compensate for logger failures, particularly post-snow coverage, by using the high correlation between loggers within the snowpack to estimate missing data (Table S2). The univariate temperature analysis applied to our sites underperformed relative to the light-based methods with the divergence between approaches most evident at the shrub-tundra site (BaseSnow) 

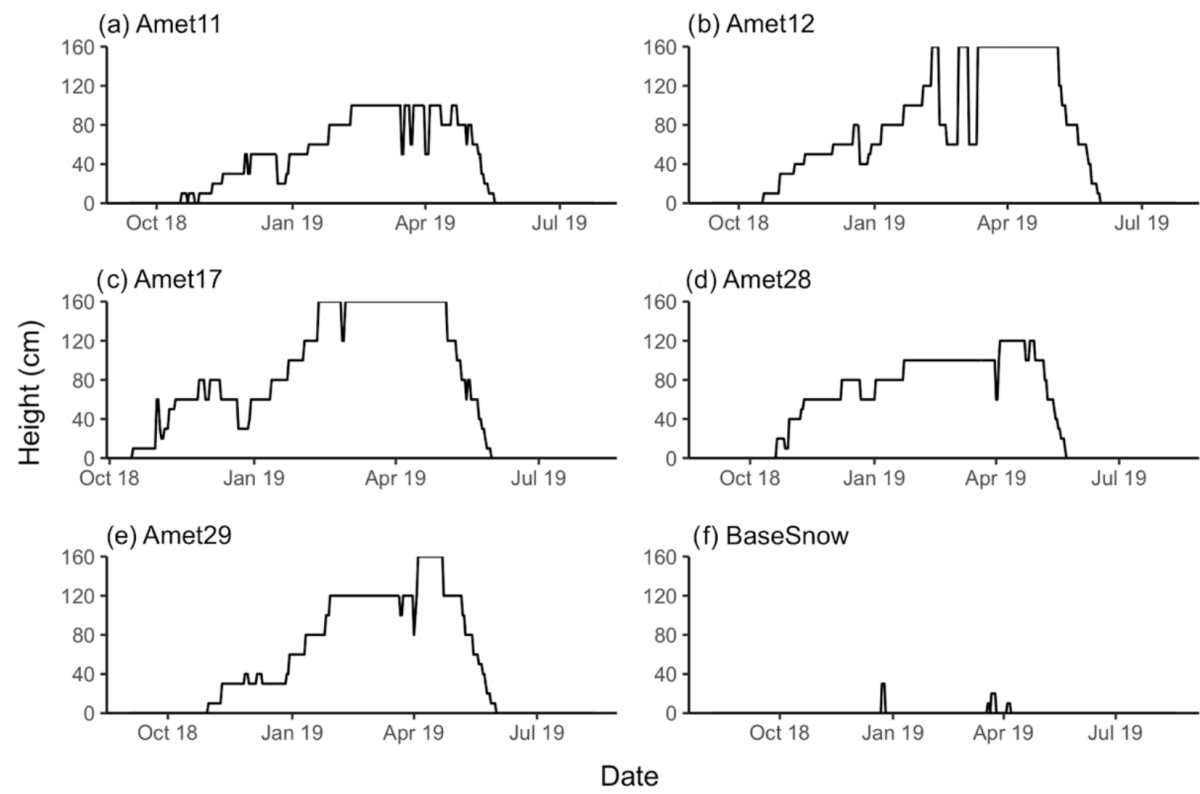

Figure 9. Snow depth over winter 2018-2019 derived from change-point analysis applied to standard deviations of daily temperature for each SCLT measurement site including (a) Amet11, (b) Amet12, (c) Amet17, (d) Amet28, (e) Amet29 and (f) BaseSnow. Top logger positions for SCLT sites ranged from $120 \mathrm{~cm}$ (Amet11 and BaseSnow) to $160 \mathrm{~cm}$ (Amet12, Amet17, Amet28, Amet29) and cannot detect snow depths above this height.

Table 3. Mean January snow depth for all six stations using all methods.

\begin{tabular}{lllll}
\hline Field site & $\begin{array}{l}\text { Raw light } \\
\text { change point }\end{array}$ & $\begin{array}{l}\text { Interpolated light } \\
\text { change point }\end{array}$ & $\begin{array}{l}\text { Interpolated light threshold } \\
\text { contours (mean) }\end{array}$ & $\begin{array}{l}\text { Raw temperature } \\
\text { change point }\end{array}$ \\
\hline Amet11 & $87.1 \mathrm{~cm}$ & $100.7 \mathrm{~cm}$ & $98.2 \mathrm{~cm}$ & $69.0 \mathrm{~cm}$ \\
Amet12 & $103.2 \mathrm{~cm}$ & $117.8 \mathrm{~cm}$ & $120.7 \mathrm{~cm}$ & $101.2 \mathrm{~cm}$ \\
Amet17 & $100.6 \mathrm{~cm}$ & $120.1 \mathrm{~cm}$ & $119.0 \mathrm{~cm}$ & $78.7 \mathrm{~cm}$ \\
Amet28 & $101.3 \mathrm{~cm}$ & $107.6 \mathrm{~cm}$ & $111.5 \mathrm{~cm}$ & $96.8 \mathrm{~cm}$ \\
Amet29 & $98.7 \mathrm{~cm}$ & $115.2 \mathrm{~cm}$ & $114.0 \mathrm{~cm}$ & $81.9 \mathrm{~cm}$ \\
BaseSnow & $10.6 \mathrm{~cm}$ & $17.3 \mathrm{~cm}$ & $23.0 \mathrm{~cm}$ & $0 \mathrm{~cm}$ \\
\hline
\end{tabular}

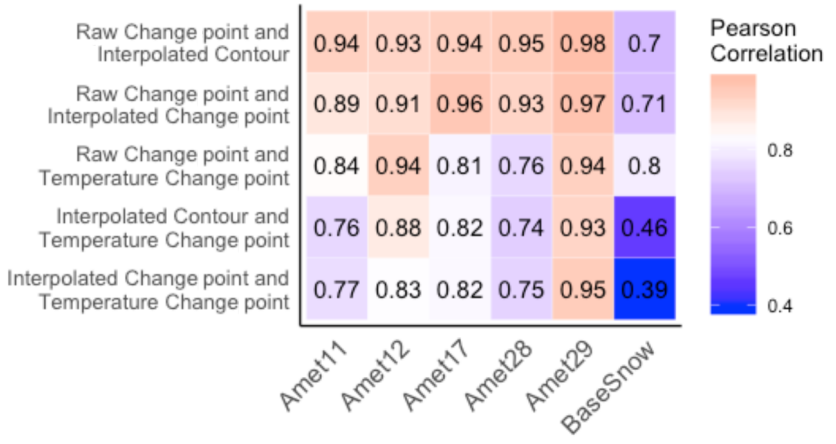

Figure 10. Pearson correlation coefficients $(r)$ comparing estimated snow depths from December 2019 and January 2020, between methods for each site.
(Fig. 10). The snowpack at this site was inferred to be dense due to wind packing and thus would experience greater diurnal temperature variability because of a higher thermal conductivity compared to a forest site (Domine et al., 2016; Sturm et al., 1997). The high light intensities outside of the snowpack induced by the albedo effect provided a fairly unambiguous contrast with the lower light intensities within the snowpack (Fig. 7), allowing for depth determination of a snowpack that is typically difficult to characterize (Domine et al., 2019).

As elucidated by Sturm et al. (2001), snow cover is sensitive to local micro-climate, vegetation cover and topography. These variables are not broadly represented in current weather monitoring infrastructure deployed near urban centres or airports (Goodison, 2006). The lack of weather stations recording snow depth adjacent to our field sites makes it difficult to validate results from most SCLT sites. However, Amet 17 is located approximately $5 \mathrm{~km}$ from Goose 


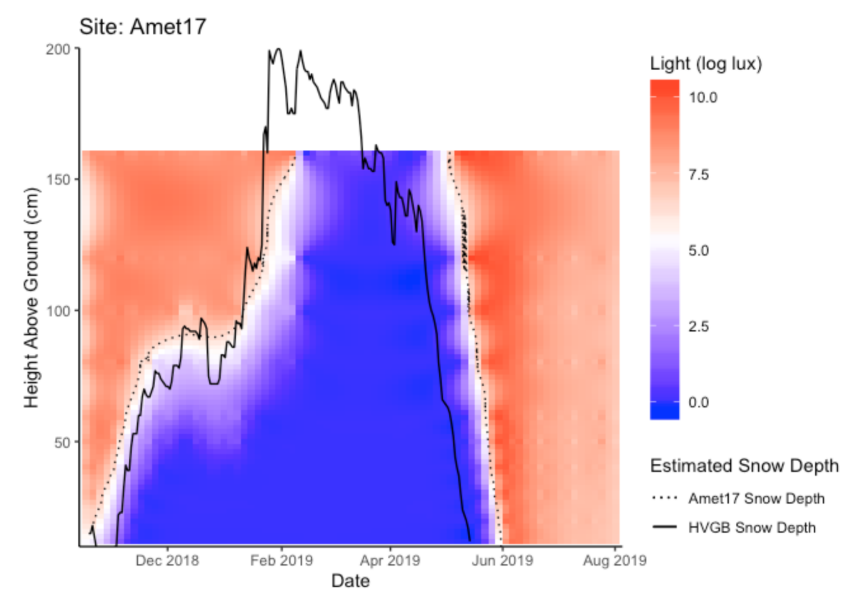

Figure 11. Estimated snow depth at Amet17 site (black dotted line) using interpolated SCLT data overlaid with snow depth measured for winter 2018-2019 at Goose Bay Airport (black solid line).

Bay Airport, which has a weather station measuring snow depth, though this site is found in an open clearing and at a site that is $200 \mathrm{~m}$ lower than Amet17 (Environment and Climate Change Canada, 2020). Comparing the two 2018-2019 snow depths from both sites shows high general agreement $(r=0.98$ for daily snow depths from December to January, $n=112$ ), but Amet17 showed a longer overall snow season and a significantly later snowmelt than at Goose Bay Airport (Fig. 11). This difference is not unexpected as Brown et al. (2003) showed a thicker peak snow depth and longer snow duration at forested versus open snow course sites (currently inactive) near Goose Bay. Later snowmelt at Amet17 can also be inferred from a site visit to Amet17 in 2020 (25 March), which showed a significantly thicker snowpack at Amet17 (95 $\pm 5 \mathrm{~cm}$; Fig. S4) than contemporaneously measured at Goose Bay Airport $(52 \mathrm{~cm})$ (Environment and Climate Change Canada, 2020).

To further assess the SCLT approach, we compared estimated snow depths at our field sites to co-located estimates from the daily Canadian Meteorological Centre (CMC) snow depth product (Brown and Brasnett, 2010). CMC daily snow depths are derived using in situ snow depth observations, statistical interpolation, and a first-guess field from a snow accumulation and melt model (Brown et al., 2003; Brown and Brasnett, 2010) (Fig. 12). The CMC product is generated at a $24 \mathrm{~km}$ spatial resolution and has reduced performance in areas with sparse in situ snow monitoring networks like Labrador. Our comparison shows that snow onset, melt and daily accumulations patterns are similar to the SCLT derived snow depth estimates (Fig. 12). MAE between December-January CMC snow depths and lightbased SCLT snow depths was 19, 2, 5, 35, 39 and $4 \mathrm{~cm}$ for Amet11, Amet12, Amet17, Amet28, Amet29 and BaseSnow, respectively. MAE between snow duration was 27, 14, 2, 10, 4 and 129d for Amet11, Amet12, Amet17, Amet28,
Amet29 and BaseSnow, respectively. Both Amet11/Amet12 and Amet28/Amet29 shared respective grid cells; thus the differences between these SCLT sites reflect influences of vegetation, elevation and potential snow drift. Unfortunately, due to the lack of snow measurement throughout northern Labrador (Mekis et al., 2018), the CMC dataset is unlikely to provide a useful validation against BaseSnow.

\subsection{Limitations and opportunities}

The results in this study have provided a direct workflow for estimating snow depth from SCLT data, though the proposed method will require further optimization and refinement. For example, our analysis did not directly evaluate the impacts of latitude, canopy cover, logger configuration and ground condition on SCLT results. Each of these factors and their corresponding influence on light transmission under snow and no-snow conditions make the universal application of particular light thresholds unlikely. The specific sensor arrangement of SCLT stakes may also require refinement and customization for indices studied. Winter 2018-2019 far exceeded normal snow depths in coastal Labrador (Fig. S5), resulting in data gaps mid-winter. The configuration in this study was designed for investigations of ground thermal impacts of snow cover in discontinuous permafrost in Labrador, which typically are largest when snow cover is shallower than $100 \mathrm{~cm}$ (Way and Lewkowicz, 2018). For hydrological applications, uniform sensor arrangement at a given interval (e.g. 5-10 cm) may be preferable.

At follow-up visits to several of our sites, we experienced water damage to HOBO MX2202 Pendant wireless temperature/light loggers, leading to battery failure and a cessation of data collection despite their reported waterproof casing. We have interpreted this to be a result of bowing of the logger casing because we overtightened the screws when affixing loggers to the wooden stakes (Fig. 3). It is advised that in the future these loggers are loosely attached to stakes to maintain the integrity of the logger structure. Field visits to sites also suggest that maintaining a consistent measurement height may be challenging in areas with significant frost heave from year to year; therefore alternative anchoring may be needed for examining changes at a site over multi-year periods. The widespread applicability of SCLT will depend on further testing at high latitudes where the lack of light availability during December and January may limit its utility during portions of the winter. However, this concern may be limited to the short periods of complete darkness as we observed substantial light reflection from high albedo tundra snow cover at our highestlatitude site (BaseSnow) even in December. Exploring the potential utility of combining light intensity and temperature together with more advanced predictive modelling may further mitigate this concern. We would also recommend that a specific sensor arrangement pointing south or towards the most open portion of the canopy could be adopted to enhance light intensity contrasts at low sun angles. 
(a) Amet11

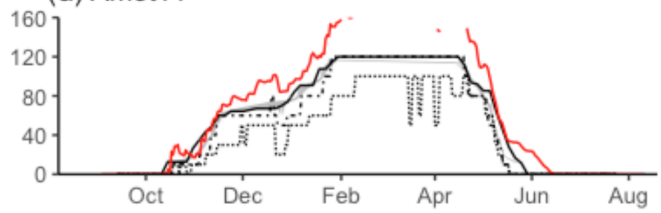

(c) Amet17

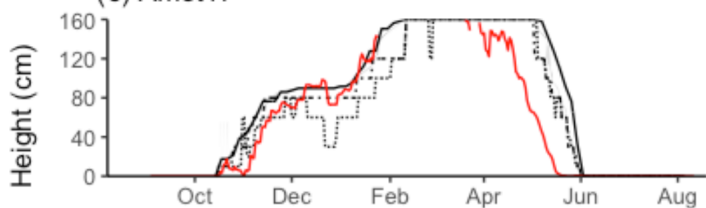

(e) Amet29

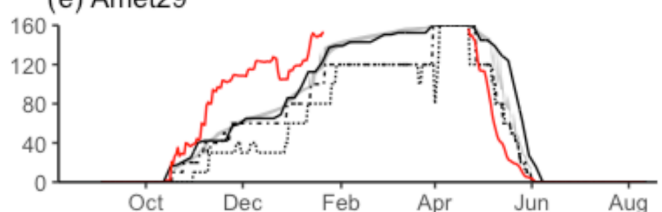

Date (2018-2019) (b) Amet12

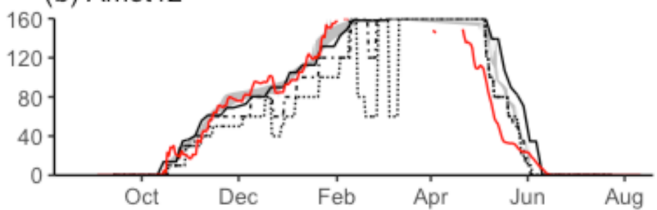

(d) Amet28

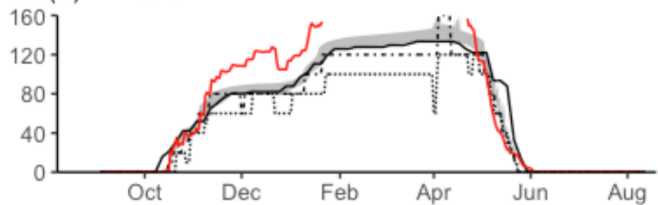

(f) BaseSnow

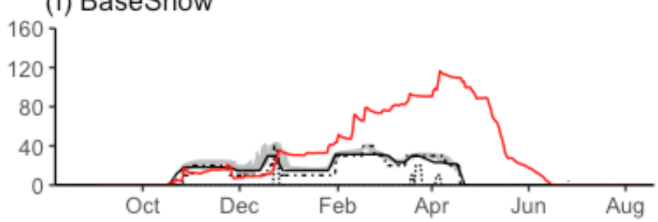

Contours — Interpolated Change point $\cdots .$. Raw Change point ....... Temperature Change point _ CMC

Figure 12. Comparison of snow depths derived with light and temperature-based methods and Canadian Meteorological Centre (CMC) snow depth analysis data (Brown and Brasnett, 2003) for (a) Amet11, (b) Amet12, (c) Amet17, (d) Amet28, (e) Amet29 and (f) BaseSnow. Snow depth estimates are provided for interpolated contours using minimum and maximum snow cover thresholds (grey shading), interpolated change-point analysis (black line), raw change-point analysis (dot-dashed line), temperature change-point analysis (dotted line) and modelled CMC snow depth at the associated grid cell (red line).

Overall, the SCLT method was found to provide robust and cost-efficient snow depth estimation in regions that are not suitable for outfitting with full weather stations. We unambiguously show that light intensity is a clearer metric for estimating daily snow depth than temperature-only methods. Further analysis combining the light intensity measurements with temperature within the snowpack will allow for a more robust snowpack characterization than available through the use of time-lapse-photography-based methods. The dual measurements collected by the SCLT technique coupled with ground temperature measurements will also enable simplified characterizations of temperature gradients within the snowpack and at depth as a coupled system (Fig. 13). Further studies should explore how SCLT can be applied to better understand other snowpack characteristics including density, grain size and effective thermal conductivity.

\section{Conclusion}

Improved monitoring and characterization of a changing snowscape is imperative to conservation, planning and climate adaptation across the globe but particularly in subarctic and Arctic regions. Snow characterization under natural environments is currently lacking in most northern environments with measurement stations mostly in open areas near airports

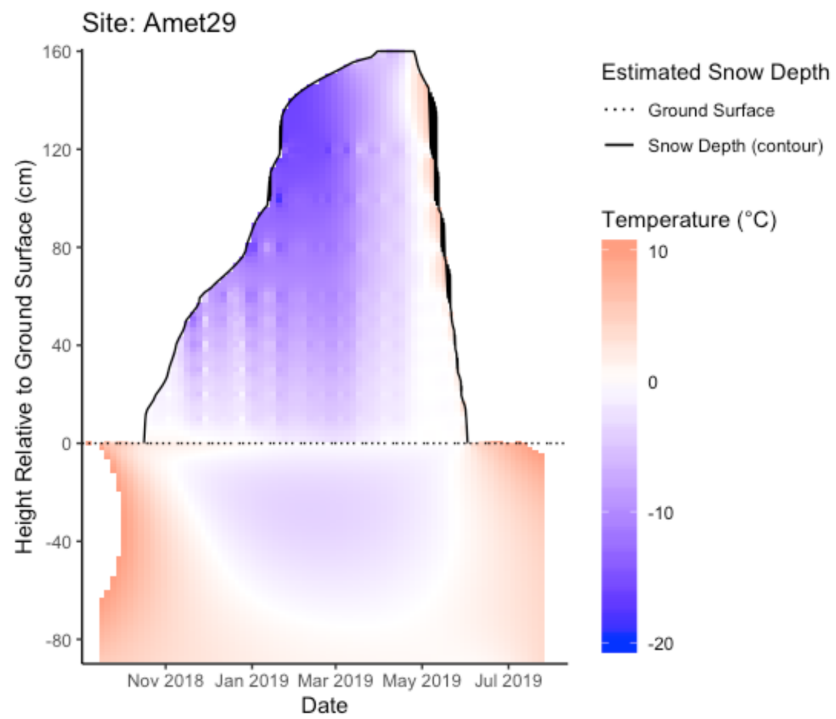

Figure 13. $X-Y-Z$ plot showing interpolated temperatures for Amet29 within the snowpack and the underlying soil (maximum depth: $85 \mathrm{~cm}$ ). Snowpack height is estimated using the interpolated light threshold contour (mean) (black line) and ground temperatures were recorded at 5 and $85 \mathrm{~cm}$ depth with a HOBO Pro V2 data logger. 
or communities, making snow studies outside of these regions dependent on snow courses and remote sensing (Brown et al., 2003; Goodison, 2006; Pulliainen et al., 2020). In this study, we introduce a novel method (SCLT) for characterizing snow conditions in remote northern environments that uses a combination of vertically arranged light and temperature loggers. We present three different methods for analyzing SCLT data, including a temperature-only approach for comparison with prior studies. Our results broadly show that raw and interpolated SCLT data can be used to efficiently characterize snow depth over full snow seasons at sites that varied considerably in ecotype and inferred snow characteristics. All SCLT-based snow estimation techniques provided clear advantages over the temperature-only approach, with the latter performing particularly poorly where snow density was inferred to be higher (shrub tundra).

The development of the SCLT method as a cost-effective measurement technique aims to help fill knowledge gaps in snow-vegetation interactions and to facilitate a wider snow monitoring network in remote areas under natural conditions. The method requires further research and refinement; however, these preliminary results are sufficiently promising that deployment of SCLT across northern research basins for testing purposes may be desirable. Applying this new method will improve our understanding of the changing cryosphere, local hydrology, and climate change impacts on ecosystems and biodiversity. Further elucidation of snow-vegetationpermafrost interactions will also aid community development, local travel safety and cultural practices.

Code and data availability. The SCLT data contribute to a larger dataset presented by Way and Lewkowicz (2018) that will be made available through Nordicana D. The R v3.6.0 or RStudio v1.2.1335 code for (a) inputting and pre-processing HOBO Pendant light/temperature CSV data, (b) determining light thresholds, and (c) snow depth evaluation through change-point analysis and interpolation is available through the authors' ResearchGate repository at the DOI links below. Additional code is available upon request.

SCLT data pre-processing:

https://doi.org/10.13140/RG.2.2.17281.48483 (Tutton and Way, 2019a).

SCLT threshold determination:

https://doi.org/10.13140/RG.2.2.14093.15841 (Tutton and Way, 2019b).

SCLT snow cover determination (change point): https://doi.org/10.13140/RG.2.2.35064.67843 (Tutton and Way, 2020).

Supplement. The supplement related to this article is available online at: https://doi.org/10.5194/tc-15-1-2021-supplement.

Author contributions. RGW established snow stake field sites as part of a wider permafrost monitoring network. RJT and RGW col- lected and analyzed field data and reviewed results relative to local weather monitoring stations. RJT and RGW drafted the final manuscript.

Competing interests. The authors declare that they have no conflict of interest.

Acknowledgements. The authors would like to acknowledge that research activities were undertaken on land originally and contemporarily occupied by the Innu and Inuit people of Labrador represented by the Innu Nation, Nunatsiavut Government and NunatuKavut Community Council. We would like to thank the Nunatsiavut Government and the Western Newfoundland and Labrador Field Unit of Parks Canada for direct logistical and research support for activities at the Torngat Mountains Basecamp and Research Station. This research benefited from conversations and/or logistical support from Caitlin Lapalme, Darroch Whitaker, Rodd Laing, Antoni Lewkowicz, Ross Brown, Philip Bonnaventure, Luise Hermanutz, Andrew Trant, Sharon Smith, Charlene Kippenhuck, George Russell Jr., Paul McCarney, Yifeng Wang and Taylor Larking. This project was logistically supported by Queen's University, the Labrador Institute of Memorial University of Newfoundland and the Nunatsiavut Government.

Financial support. This research has been supported by ArcticNet (grant no. 20)), the W. Garfield Weston Foundation and Queen's University.

Review statement. This paper was edited by Elizabeth Bagshaw and reviewed by Michael Prior-Jones and one anonymous referee.

\section{References}

Aminikhanghahi, S. and Cook, D. J.: A Survey of Methods for Time Series Change Point Detection, Knowl. Inf. Syst., 51, 339-367, https://doi.org/10.1007/s10115-016-0987-z, 2017.

Archer, D.: Snow measurement. Encyclopedia of Hydrology and Lakes, Encyclopedia of Earth Science, Springer, Dordrecht https://doi.org/10.1007/1-4020-4497-6_206, 1998.

Banfield, C. E. and Jacobs, J. D.: Regional Patterns of Temperature and Precipitation for Newfoundland and Labrador During the Past Century, Can. Geogr., 42, 354-364, https://doi.org/10.1111/j.1541-0064.1998.tb01351.x, 1998.

Barrette, C., Brown, R., Way, R., Mailhot, A., Diaconescu, É. P., Grenier, P., Chaumont, D., Dumon, D., Sévigny, C., Howell, S., and Senneville, S.: Nunavik and Nunatsiavut Regional Climate Information Update, in Nunavik and Nunatsiavut: From science to policy. An Integrated Regional Impact Study (IRIS) of climate change and modernization, second iteration, p. 62, ArcticNet Inc, Quebec City, Canada, 2020.

Beaulieu, C., Chen, J., and Sarmiento, J. L.: Change-point analysis as a tool to detect abrupt climate variations, Philos. T. Roy. A., 370, 1228-1249, https://doi.org/10.1098/rsta.2011.0383, 2012. 
Bird, R. E. and Hulstrom, R. L.: Simplified clear sky model for direct and diffuse insolation horizontal surfaces, available at: https://www.nrel.gov/grid/solar-resource/clear-sky.html (last access: 5 June 2020), 1981.

Boelman, N. T., Liston, G. E., Gurarie, E., Meddens, A. J. H., Mahoney, P. J., Kirchner, P. B., Bohrer, G., Brinkman, T. J., Cosgrove, C. L., Eitel, J. U. H., Hebblewhite, M., Kimball, J. S., LaPoint, S., Nolin, A. W., Pedersen, S. H., Prugh, L. R., Reinking, A. K., and Vierling, L. A.: Integrating snow science and wildlife ecology in Arctic-boreal North America, Environ. Res. Lett., 14, 010401, https://doi.org/10.1088/1748-9326/aaeec1, 2019.

Bojinski, S., Verstraete, M., Peterson, T. C., Richter, C., Simmons, A., and Zemp, M.: The Concept of Essential Climate Variables in Support of Climate Research, Applications, and Policy, B. Am. Meteorol. Soc., 95, 1431-1443, https://doi.org/10.1175/BAMSD-13-00047.1, 2014.

Bongio, M., Arslan, A. N., Tanis, C. M., and De Michele, C.: Snow depth estimation by time-lapse photography: Finnish and Italian case studies, The Cryosphere Discuss., https://doi.org/10.5194/tc-2019-193, in review, 2019.

Brown, R., Lemay, M., Allard, M., Barrand, N. E., Barrette, C., Bégin, Y., Bell, T., Bernier, M., Bleau, S., Chaumont, D., Dibike, Y., Frigon, A., Leblanc, P., Paquin, D., Sharp, M. J., and Way, R.: Climate variability and change in the Canadian Eastern Subarctic IRIS region (Nunavik and Nunatsiavut), https://doi.org/10.13140/RG.2.1.3745.0323, 2012.

Brown, R. D. and Brasnett, B.: Canadian Meteorological Centre (CMC) Daily Snow Depth Analysis Data, Version 1. updated annually, NASA National Snow and Ice Data Center Distributed Active Archive Center [snow depth], https://doi.org/10.5067/W9FOYWH0EQZ3, 2010.

Brown, R. D., Brasnett, B., and Robinson, D.: Gridded North American monthly snow depth and snow water equivalent for GCM evaluation, Atmos. Ocean, 41, 1-14, https://doi.org/10.3137/ao.410101, 2003.

Callaghan, T. V., Johansson, M., Brown, R. D., Groisman, P. Ya., Labba, N., Radionov, V., Barry, R. G., Bulygina, O. N., Essery, R. L. H., Frolov, D. M., Golubev, V. N., Grenfell, T. C., Petrushina, M. N., Razuvaev, V. N., Robinson, D. A., Romanov, P., Shindell, D., Shmakin, A. B., Sokratov, S. A., Warren, S., and Yang, D.: The Changing Face of Arctic Snow Cover: A Synthesis of Observed and Projected Changes, AMBIO, 40, 17-31, https://doi.org/10.1007/s13280-011-0212-y, 2011.

Danby, R. K. and Hik, D. S.: Responses of white spruce (Picea glauca) to experimental warming at a subarctic alpine treeline, Glob. Change Biol., 13, 437-451, https://doi.org/10.1111/j.13652486.2006.01302.x, 2007.

de Pablo, M. A., Ramos, M., and Molina, A.: Snow cover evolution, on 2009-2014, at the Limnopolar Lake CALM-S site on Byers Peninsula, Livingston Island, Antarctica., CATENA, 149, 538547, https://doi.org/10.1016/j.catena.2016.06.002, 2017.

Derksen, C., Lemmetyinen, J., Toose, P., Silis, A., Pulliainen, J., and Sturm, M.: Physical properties of Arctic versus subarctic snow: Implications for high latitude passive microwave snow water equivalent retrievals, J. Geophys. Res.-Atmos., 119, 72547270, https://doi.org/10.1002/2013JD021264, 2014.

Dickerson-Lange, S. E., Gersonde, R. F., Hubbart, J. A., Link, T. E., Nolin, A. W., Perry, G. H., Roth, T. R., Wayand, N. E., and Lundquist, J. D.: Snow disappearance timing is dominated by forest effects on snow accumulation in warm winter climates of the Pacific Northwest, United States, Hydrol. Process., 31, 18461862, https://doi.org/10.1002/hyp.11144, 2017.

Domine, F., Barrere, M., and Sarrazin, D.: Seasonal evolution of the effective thermal conductivity of the snow and the soil in high Arctic herb tundra at Bylot Island, Canada, The Cryosphere, 10, 2573-2588, https://doi.org/10.5194/tc-10-2573-2016, 2016.

Domine, F., Picard, G., Morin, S., Barrere, M., Madore, J.-B., and Langlois, A.: Major Issues in Simulating Some Arctic Snowpack Properties Using Current Detailed Snow Physics Models: Consequences for the Thermal Regime and Water Budget of Permafrost, J. Adv. Model. Earth. Sy., 11, 34-44, https://doi.org/10.1029/2018MS001445, 2019.

Environment and Climate Change Canada: Historical Climate Data - Goose A, available at: https://climate.weather.gc. ca/climate_data/daily_data_e.html?StationID $=6777$, last access: 20 July 2020.

Farinotti, D., Magnusson, J., Huss, M., and Bauder, A.: Snow accumulation distribution inferred from time-lapse photography and simple modelling, Hydrol. Process., 24, 2087-2097, https://doi.org/10.1002/hyp.7629, 2010.

Ford, J. D., Clark, D., Pearce, T., Berrang-Ford, L., Copland, L., Dawson, J., New, M., and Harper, S. L.: Changing access to ice, land and water in Arctic communities, Nat. Clim. Change, 9, 335-339, https://doi.org/10.1038/s41558-019-0435-7, 2019.

Fortin, V., Jean, M., Brown, R., and Payette, S.: Predicting Snow Depth in a Forest-Tundra Landscape using a Conceptual Model Allowing for Snow Redistribution and Constrained by Observations from a Digital Camera, Atmos. Ocean, 53, 200-211, https://doi.org/10.1080/07055900.2015.1022708, 2015.

Garvelmann, J., Pohl, S., and Weiler, M.: From observation to the quantification of snow processes with a time-lapse camera network, Hydrol. Earth Syst. Sci., 17, 1415-1429, https://doi.org/10.5194/hess-17-1415-2013, 2013.

Gilbert, S. L., Hundertmark, K. J., Person, D. K., Lindberg, M. S., and Boyce, M. S.: Behavioral plasticity in a variable environment: snow depth and habitat interactions drive deer movement in winter, J. Mammal., 98, 246-259, https://doi.org/10.1093/jmammal/gyw167, 2017.

Goodison, B.: Challenges in Snow Measurement: Solid Precipitation and Snow Cover, ECMWF Seminar on Polar Meteorology, Shinfield Park, Reading, 4-8 September 2006.

Hovelsrud, G. K., Poppel, B., van Oort, B., and Reist, J. D.: Arctic Societies, Cultures, and Peoples in a Changing Cryosphere, AMBIO, 40, 100-110, https://doi.org/10.1007/s13280-011-0219-4, 2011.

Killick, R., Fearnhead, P., and Eckley, I. A.: Optimal detection of changepoints with a linear computational cost, J. Am. Stat, Assoc., 107, 1590-1598, https://doi.org/10.1080/01621459.2012.737745, 2012.

Kinar, N. and Pomeroy, J.: Measurement of the physical properties of the snowpack, Rev. Geophys., 53, 481-544, 2015.

Leinss, S., Löwe, H., Proksch, M., Lemmetyinen, J., Wiesmann, A., and Hajnsek, I.: Anisotropy of seasonal snow measured by polarimetric phase differences in radar time series, The Cryosphere, 10, 1771-1797, https://doi.org/10.5194/tc-10-1771-2016, 2016.

Lemke, P., Ren, J. F., Alley, R. B., Allison, I., Carrasco, J., Flato, G., Fujii, Y., Kaser, G., Mote, P., Thomas, R. H., and Zhang, T.: Observations: Changes in Snow, Ice and Frozen Ground, in: 
Climate Change 2007: The Physical Science Basis, Contribution of Working Group I to the Fourth Assessment Report of the Intergovernmental Panel on Climate Change, edited by: Solomon, S., Qin, D., Manning, M., Chen, Z., Marquis, M., Averyt, K. B., Tignor, M., and Miller, H. L., Cambridge University Press, Cambridge, United Kingdom and New York, NY, USA, 2007.

Lewkowicz, A. G.: Evaluation of miniature temperature-loggers to monitor snowpack evolution at mountain permafrost sites, northwestern Canada, Permafrost Periglac., 19, 323-331, https://doi.org/10.1002/ppp.625, 2008.

Libois, Q., Picard, G., France, J. L., Arnaud, L., Dumont, M., Carmagnola, C. M., and King, M. D.: Influence of grain shape on light penetration in snow, The Cryosphere, 7, 1803-1818, https://doi.org/10.5194/tc-7-1803-2013, 2013.

Maxwell, J. B.: Climatic Regions of the Canadian Arctic Islands, Arctic, 34, 225-240, 1981.

Mekis, E., Donaldson, N., Reid, J., Zucconi, A., Hoover, J., Li, Q., Nitu, R., and Melo, S.: An Overview of Surface-Based Precipitation Observations at Environment and Climate Change Canada, Atmos. Ocean, 56, 71, https://doi.org/10.1080/07055900.2018.1433627, 2018.

Mortimer, C., Mudryk, L., Derksen, C., Luojus, K., Brown, R., Kelly, R., and Tedesco, M.: Evaluation of long-term Northern Hemisphere snow water equivalent products, The Cryosphere, 14, 1579-1594, https://doi.org/10.5194/tc-14-1579-2020, 2020.

Nychka, D., Furrer, R., Paige, J., and Sain, S.: fields: Tools for spatial data, $\mathrm{R}$ package version 9.8-6, https://doi.org/10.5065/D6W957CT, 2017.

Olsen, M. S., Callaghan, T. V., Reist, J. D., Reiersen, L. O., Dahl-Jensen, D., Granskog, M. A., Goodison, B., Hovelsrud, G. K., Johansson, M., Kallenborn, R., Key, J., Klepikov, A., Meier, W., Overland, J. E., Prowse, T. D., Sharp, M., Vincent, W. F., and Walsh, J.: The Changing Arctic Cryosphere and Likely Consequences: An Overview, AMBIO, 40, 111-118, https://doi.org/10.1007/s13280-011-0220-y, 2011.

Onset Computer Corporation: HOBO Pendant (R) MX Temperature/Light Data Logger, Data Loggers, available at: https: //www.onsetcomp.com/products/data-loggers/mx2202/, last access: 1 July 2020.

Perovich, D. K.: Light reflection and transmission by a temperate snow cover, J. Glaciol., 53, 201-210, https://doi.org/10.3189/172756507782202919, 2007.

Pulliainen, J., Luojus, K., Derksen, C., Mudryk, L., Lemmetyinen, J., Salminen, M., Ikonen, J., Takala, M., Cohen, J., Smolander, T., and Norberg, J.: Patterns and trends of Northern Hemisphere snow mass from 1980 to 2018, Nature, 581, 294-298, https://doi.org/10.1038/s41586-020-2258-0, 2020.

Reusser, D. E. and Zehe, E.: Low-cost monitoring of snow height and thermal properties with inexpensive temperature sensors, Hydrol. Process., 25, 1841-1852, https://doi.org/10.1002/hyp.7937, 2011.

Riley, J. L., Notzl, L., and Greene, R.: Labrador Nature Atlas: Vol. II, Ecozones, Ecoregions and Ecodistricts., 130, Nature Conservancy of Canada, Toronto, Ontario, 2013.

Roberts, B. A., Simon, N. P. P., and Deering, K. W.: The forests and woodlands of Labrador, Canada: ecology, distribution and future management, Ecol. Res., 21, 868-880, https://doi.org/10.1007/s11284-006-0051-7, 2006.
Sturm, M.: White water: Fifty years of snow research in WRR and the outlook for the future, Water Resour. Res., 51, 4948-4965, https://doi.org/10.1002/2015wr017242, 2015.

Sturm, M., Holmgren, J., König, M., and Morris, K.: The thermal conductivity of seasonal snow, J. Glaciol., 43, 26-41, https://doi.org/10.3189/S0022143000002781, 1997.

Sturm, M., Holmgren, J., McFadden, J. P., Liston, G. E., III, F. S. C., and Racine, C. H.: Snow-Shrub Interactions in Arctic Tundra: A Hypothesis with Climatic Implications, J. Climate, 14, 336-344, https://doi.org/10.1175/15200442(2001)014<0336:Ssiiat>2.0.Co;2, 2001.

Sturm, M., Douglas, T., Racine, C., and Liston, G. E.: Changing snow and shrub conditions affect albedo with global implications, J. Geophys. Res.-Biogeo., 110, G01004, https://doi.org/10.1029/2005jg000013, 2005.

Thackeray, C. W., Derksen, C., Fletcher, C. G., and Hall, A.: Snow and Climate: Feedbacks, Drivers, and Indices of Change, Curr. Clim. Change Rep., 5, 322-333, https://doi.org/10.1007/s40641019-00143-w, 2019.

Throop, J., Lewkowicz, A. G., and Smith, S. L.: Climate and ground temperature relations at sites across the continuous and discontinuous permafrost zones, northern Canada, Can. J. Earth Sci., 49, 865-876, https://doi.org/10.1139/e11-075, 2012.

Trujillo, E. and Lehning, M.: Theoretical analysis of errors when estimating snow distribution through point measurements, The Cryosphere, 9, 1249-1264, https://doi.org/10.5194/tc-9-12492015, 2015.

Tutton, R. and Way, R.: SCLT Data Pre-processing, ResearchGate, https://doi.org/10.13140/RG.2.2.17281.48483, 2019a.

Tutton, R. and Way, R.: SCLT Threshold Determination, ResearchGate, https://doi.org/10.13140/RG.2.2.14093.15841, 2019b.

Tutton, R. and Way, R.: SCLT Snow Cover Determination (Changepoint), ResearchGate, https://doi.org/10.13140/RG.2.2.35064.67843, 2020.

Wambui, G. D., Waititu, G. A., and Wanjoya, A.: The power of the pruned exact linear time (PELT) test in multiple changepoint detection, Am. J. of Theoretical and Applied Statistics, 4, 581586, 2015.

Way, R. G. and Lewkowicz, A. G.: Environmental controls on ground temperature and permafrost in Labrador, northeast Canada, Permafrost Periglac., 29, 73-85, https://doi.org/10.1002/ppp.1972, 2018.

Way, R. G., Lewkowicz, A. G., and Bonnaventure, P. P.: Development of moderate-resolution gridded monthly air temperature and degree-day maps for the Labrador-Ungava region of northern Canada, Int. J. Climatol., 37, 493-508, https://doi.org/10.1002/joc.4721, 2017.

Wilcox, E. J., Keim, D., de Jong, T., Walker, B., Sonnentag, O., Sniderhan, A. E., Mann, P., and Marsh, P.: Tundra shrub expansion may amplify permafrost thaw by advancing snowmelt timing, Arctic Sci., 5, 202-217, https://doi.org/10.1139/as-20180028, 2019.

Wolf, J., Allice, I., and Bell, T.: Values, climate change, and implications for adaptation: Evidence from two communities in Labrador, Canada, Global Environ. Chang., 23, 548-562, https://doi.org/10.1016/j.gloenvcha.2012.11.007, 2013. 